The mode of its evacuation is the most common one taken by these abscesses, and it is worthy of notice that in this case the usual concomitants of iliac abscess, viz.: resical tenesmus, and a senso of weight about the pelvis, were not complained of.

\title{
MENTAL TOXICOLOGY.
}

[Communicated, by request, for the Boston Medical and Surglcal Journal.]

By JaMe8 H. DenNy, M.D.

Mental Toxicology may be defined to be that branch of psychological medicine which discusses the action of mental processes in impairing or destroying vital functions. As it is unusual to classify the deleterious influences of the mind upon the body among toxicological agents, it will be necessary to be somewhat preciso in definition. Mind is complex, and can only be defined by its attributes.

Mental attributes, or processes, are those of (1) Cognition, or "the act of energy in thought * * * during which man attains to knowledge of a thing."-(LAYCOCK.) (2) Emotion, or "the phenomena of pleasure and pain." (3) Volition, or "the phenomena of desire and will."-(Hamilton.)

The vital processes are Innervation, Circulation, and Nutrition.

A poison is defined by Dr. Taylor as "A substance which, when absorbed into the blood, is capable of seriously affecting health or of destroying life."

Neurotic poisons act principally through the cercbro-spinal nervous system, and primarily affect the vital process of innervation. They involve circulation and nutrition secondarily, according to their mode of exhibition. Giddiness, delirium, stupor, paralysis and convulsion are some of the prominent symptoms produced by neurotic poisons, of which stryclinia and opium are familiar examples. The convulsive action of the cerebro-spinal nerves in chorca is similar to the effects of this class of poisons.

Irritant poisons mainly implicate the ganglionic system, and the vital process of circulation. Irregular pulse, cold pallid skin, nausea and purging, characterize the effects of these poisons, of which arsenic is a typical example.

The symptoms of cholera-although the cerebro-spinal nerves may be also involved-are analogous to irritant poisoning.

Having thus imperfectly glanced at the classification and effects of material poisons, I shall endeavor to show that similar symptoms may be caused by the toxical agency of the mind acting through the cerebro-spinal system as a mental neurotic poison, and through the ganglionic system as a mental irritant poison; that in both instances it is "capablo of seriously affecting health, or of destroying life," and may therefore be entitled to rank with a "poisonous substance absorbed into the blood." 
In searching for a mental neurotic poison, it will be requisite to analyze some of the attributes of mind, even at the risk of seeming pedantry.

Among other sub-divisions of the cognitive faculty, Sir William Hamilton includes the special faculty termed the Presentative, or that of external perception, through the medium of which there is "a presentation of the order of nature to the consciousness through the senses." Knowledge results. Another special faculty is the Representative, or Imagination. "It is the power which the mind has of holding up vividly before itself the ideas which it has recalled into consciousness."-(LAYCOCK.) Finally, the power which the mind possesses of modifying the knowledge which it receives, in conformity to its proper nature, is called the Regulative Faculty, Reason, or Common Sense. It is the co-ordinating power, by which harmony is maintained in the other faculties.

Will and Desire can only be manifested through the cognition - Ignoti nulla cupido." "Mere cognition is insufficient to determine the will, without the intermediate influence of the emotions." The will, moreover, is a deliberate, and desire a "blind and fatal tendency to act."-(HAMILTON.)

Whenever the control of the regulative faculty is lessened, and imagination is allowed to usurp the place of cominon sense, a predisposition is formed, both in society and in the individual, favorable for the production of specific disease, and death, through the agency of mental impressions. Ignorance is the most frequent cause of this loss of regulative power. Morbid sympathy, which is a modification of desire, "or a blind and fatal tendency to act," is the common result of this condition of mind.

Desire, then, as thus explained, I shall endeavor to establish as an acute mental neurotic poison. In illustration, I shall refer to the epidemics of the spasmodic dance of St. John, the convulsive dance of St. Vitus, particularly in Germany, and to the tetanic bacchanal of tarantism in Italy, during the middle ages, also to certain fanaticisms in more modern days.

Every country in Europe had been devastated during the middle ages by plagues and famines, in quick succession. Civilization was rude, and human life was lightly esteemed. Law, which bears the same relation to society as the will to the individual, was but little regarded. Ignorance, superstition and fear every where prevailed. The terrible plague strewed the highways with thousands of un sepulchred dead, whose loathsome terrors spread pestilential horror among perishing millions.

Ignorance ascribed the origin of the pestilence to the poisoning of the wells by the Jews, and reason yielded to a fearful imagination. Popular passion raged with malignant fury, and a "blind desire" for vengeance culminated in frightful deaths by fire and sword to thirty thousand Israelites. 
Morbid sympathy originated the brotherhood of the Flagellants, who, in frenzied multitudes of thousands, made penitential pilgrimages all over Europe, scourging themselves with bloody zcal, and offering prayers for the averting of the plague.

This diffused morbid sympathy, developed into an imitative impulse, manifested itself as an acute mental cerebro-spinal poison in the extraordinary epidemic of the howling dance of St. John. Dr. Hecker says that, just after tho subsidence of the Black Death in 1374, "assemblages of men and women were scen at Aix.la.Chapelle, who had come out of Germany, and who, united by one common delusion, exhibited to the public, both in the streets and in the churches, the following strange spectacle. They formed circles hand in hand, and appearing to have lost all control over their senses, continued dancing for hours in wild delirium, until they foll exhausted." Some. times the attack commenced with convulsions, and those affected foll senscless, panting and laboring for breath, and then they, suddenly springing up, began to dance with strange contortions. At Metz the streets were crowded with 1100 shrieking dancers. "Peasants loft their ploughs, mechanics their workshops, housewives their domestic duties, and children their parents"-having imbibed the poison of this mental infection, and joined in the corybantic carnival -ignorantly impelled by an "all conquering imagination to imitate what they liad seen."

The dance of St. Vitus was of similar character, and depended upon that "disposition of mind, altogether so peculiar to the middle ages," and which has partially beon counteracted in its poisonous influence by the antidotal diffusion of popular knowledge in modern times. It attacked rich and poor, strong and weak, indiscriminately. Multitudes would violently jump, roar, and dance with such fury and extravagance of action, that many died from the violence of the attack, whilo others were paralyzed, and suffered with a tormenting tympany.

One form of this Chorea Sancti Viti was called by Paracelsus"Chorea Imaginativa"; and another, "Chorea Lasciva." Ho taught that it arose from sensual desires depending on the will. It is probable that it was aggravated by what Mr. Baker Brown would call "peripheral irritation of the pudic nerve." The theory of reflex excitalility seems to have been understood, for Paracelsus recom. mended severe corporeal chastisement as the most efficient therapeutical agent. The treatment which was efficacious then, would not, unfortunatcly, receive commondation now, notwithstanding the vaunt. ed diffusion of knowledge. A very similar kind of chorea lasciva, depending upon like causes, and epidemic now in the form of "Black Crook," is treated with popular applause, and lavish remuncration. Woll might the medical and moral philosopher meet in consultation, to determine whether such poisoning were better combated by the cautery, "clitoridectomy," or by a more wisely ordered system of public education! 
Tarantism was another bacchanalian epidemic, characterized by delirious shouting, laughing, singing, nausea, vomiting, and exstatic, untiring dancing. It was originally attributed to the actual poison of the tarantula, but precisely similar cerebro-spinal symptoms were produced by the mental neurotic poison of desire, developed into a morbid, sympathetic, imitative impulse. Dr. Murray states, that "bachelors, widows, widowers and old maids, are among the many victims of a gloomy solitude, which so often affects the mind as to implicate the body in disease."

In the fifteenth century there was a convent epidemic, which as it occurs in a modified nature now, is of some interest in illustration of the toxical dangers incident to the unwedded. "A nun in a German nunnery fell to biting all her companions, and shortly all the other nuns-being melancholy and hysterical-became mordacious, and began biting each other, until, spreading from convent to convent, the propensity was vigorously manifested in the convents of Rome." It is well to observe, in warning, that it may be a similar rabid "vis a tergo" which exhibits itself in vicious tendencies to back-biting in modern times. Statesmen even might profit by reflecting on this form of mental neurotic poisoning.

The manifestations of the pretended victims of witcheraft were characterized by the symptoms produced by acute cerebro-spinal poisons, and as firing was mercilessly employed as a remedy, wo may suppose that our forefathers reposed confidence in the actual cautery. The Rev. Mr. Parris, who was a clergyman in Salem village in 1692-having consumed his vital energies in his weclcly sermons - transmitted a diseased innervation to his child. Even as now such heinous crimes of hereditament are attributed to supernatural agencies, rather than to culpable violations of natural laws, and are dignified with all the sonorous titles of a frightfully ample nosology, so the reverend poisoner called the curse of his own entailment, witchcraft. It became contagious through morbid sympathy, and exhibited every variety of stupor, delirium, paralysis and convulsion. Dislocation of the jaws, through the violent trismus which supervened, was of frequent occurjence.

Those who have scen yelling, groaning, writhing, swooning, convulsed crowds of negroes in the agony of worship, will recognize the effect of an acute mental neurotic poison.

[To be concluded.]

\section{CON'TRIBUTIONS TO DERMATOLOGY.}

(Continued from page 217.)

HaVING marked out and initiated a course of treatment, as far as practicable, for internal medicines, for food, cleanliness, salubrious air, clothing and whatever else may be decmed essential in the do- 